\title{
Hand-foot syndrome due to hepatitis C therapy
}

\author{
Marlone Cunha-Silva ${ }^{1}$ \\ Daniel Mazo ${ }^{\mathbf{1 , 2}}$ \\ Raquel Arrelaro ${ }^{1}$ \\ Nayana Vaz ${ }^{1}$ \\ Marcello Rabello \\ Tirzah Lopes ${ }^{1}$ \\ Bárbara Corrêa ${ }^{1}$ \\ Ana Beatriz Torino ${ }^{3}$ \\ Maria Cintra ${ }^{3}$ \\ Sonia Lorena ${ }^{\mathbf{1}}$ \\ Tiago Sevá-Pereira ${ }^{1}$ \\ Jazon Almeida ${ }^{1}$
}

1. Department of Gastroenterology, School of Medical Sciences, University of Campinas (UNICAMP), Campinas, SP, Brasil
2. Department of Gastroenterology, University of Sao Paulo School of Medicine (FMUSP), São Paulo, SP, Brasil
3. Department of Dermatology, School of Medical Sciences, University of Campinas (UNICAMP), Campinas, SP, Brasil

http://dx.doi.org/10.1590/1806-9282.64.05.415

\section{SUMMARY}

INTRODUCTION. Direct-acting antivirals are new drugs for chronic hepatitis C treatment. They are usually safe and well tolerated, but can sometimes cause serious adverse effects and there is no consensus on how to treat or prevent them. We described a case of handfoot syndrome due to hepatitis $C$ virus interferon-free therapy.

METHODS. We report the case of a 49-year-old man with compensated liver cirrhosis due to chronic hepatitis $C$ genotype 1 , treatment-naive, who started viral treatment with sofosbuvir, simeprevir and ribavirin for 12 weeks.

RESULTS. At the sixth week of treatment he had anemia, requiring a lower dose of ribavirin. At the tenth week, he had erythematous, pruritic, scaly and flaky lesions on hands and feet, which showed a partial response to oral antihistamines and topical corticosteroids. It was not necessary to discontinue antiviral treatment, but in the first week after the end of treatment, there was worsening of injuries, including signs of secondary infection, that required hospitalization, antibiotics and oral corticosteroid, with progressive improvement. Biopsy of the lesions was consistent with pharmacodermia. The patient had sustained a virological response, despite the side effect. He had a history of pharmacodermia one year ago attributed to the use of topiramate, responsive to oral corticosteroid.

CONCLUSION. Interferon-free therapies can rarely lead to severe adverse reactions, such as skin lesions. Patients receiving ribavirin combinations and those who had a history of pharmacodermia or skin disease may be more susceptible. There is no consensus on how to prevent skin reactions in these patients.

KEYWORDS: Hepatitis C. Antiviral Agents. Drug-related Side Effects and Adverse Reactions. Hand-Foot Syndrome.

\section{INTRODUCTION}

Hepatitis C virus (HCV) infection are one of the leading causes of chronic liver disease worldwide'. The inflammation caused by the virus leads to liver fibrosis, cirrhosis, and complications, such as hepatocellular carcinoma. Treating the disease is essential, because it blocks the inflammation, reducing the fibrosis progression and the mortality associated with the infection².

For many years, HCV therapy has consisted of the combination of pegylated interferon and ribavirin for 24 or 48 weeks. With this regimen, genotype 1 patients had a around $50 \%{ }^{2}$ of chance to sustain virological response (SVR). However, this treatment was 
accompanied by many side effects, such as anemia, leukopenia, thrombocytopenia, flu-like symptoms, blood glucose changes, alterations in thyroid function, anxiety and mood disorders, teratogenicity and autoimmunity ${ }^{2-4}$.

New drugs that act against the virus replication were developed, known as DAAs, or direct-acting antiviral agents. Their use without interferon improved treatment efficacy and safety, reducing the adverse effects, especially in cirrhotic patients, a more susceptible population ${ }^{2-4}$. In Brazil, the most used DAAs are sofosbuvir (a nucleotide analog inhibitor of RNA polymerase), daclatasvir (a NS5A inhibitor) and simeprevir (a NS3-4A protease inhibitor) ${ }^{5}$.

There are few reports of side effects due to interferon-free therapy ${ }^{6}$. They are usually mild and do not require discontinuation of treatment. However sometimes they can be severe and there are scarce data on how to avoid them. Here, we report a case of hand-foot syndrome due to HCV interferon-free treatment.

\section{CASE REPORT}

A 49 year-old man with HCV related liver cirrhosis, genotype 1 and alcohol abuse was referred to our outpatient clinic for HCV therapy assessment. He was HCV treatment naïve, with arterial hypertension, diabetes, anxiety disorder and a tobacco user. He denied previous gastrointestinal bleeding, ascites or hepatic encephalopathy. He had a compensated liver function (Child-Pugh A, MELD 6), with a liver stiffness by Fibroscan ${ }^{\circledR}$ of 47.2 kPascal, compatible with Metavir F4 (cirrhosis). The upper digestive endoscopy revealed portal hypertension with esophageal varices. Baseline exams were as follows: hemoglobin: $15 \mathrm{mg} / \mathrm{dL}$, leukocytes: $8,710 / \mathrm{mm}^{3}$, platelet count: 193,000/ $\mathrm{mm}^{3}$, total bilirubin: $0.99 \mathrm{mg} / \mathrm{dL}$ [reference value $(\mathrm{RV})<1.2$ ], urea: $41 \mathrm{mg} / \mathrm{dL}(\mathrm{RV}<43)$, creatinine: $0.9 \mathrm{mg} / \mathrm{dL}(\mathrm{RV}<1,2)$, alanine aminotransferase: $82 \mathrm{IU} / \mathrm{L}(\mathrm{RV}<50)$, aspartate aminotransferase: 48 IU/L (RV < 50), alkaline phosphatase: 117 IU/L (RV $<120$ ), gamma glutamyl transferase: $300 \mathrm{IU} / \mathrm{L}(\mathrm{RV}$ $<38$ ), albumin: $4.0 \mathrm{~g} / \mathrm{dL}$ (RV 3.5-5.2), INR: 0.9 (RV

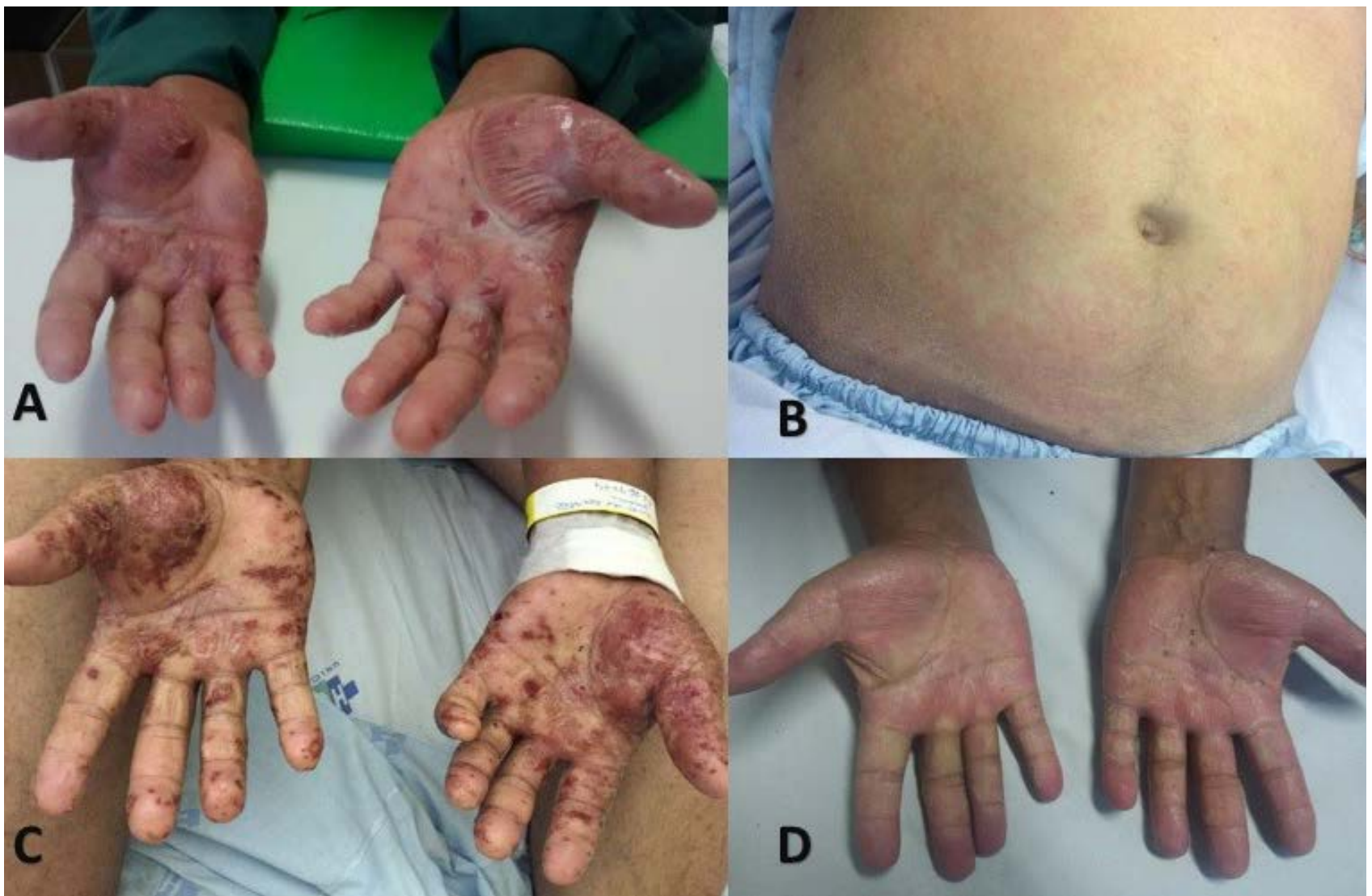

FIGURE 1. A) Erythematous, pruritic, scaly and flaky lesions on hands and B) abdomen (at tenth week of HCV treatment). C) Peeling areas, break blisters, skin fissures with bleeding and signs of secondary infection on hands (one week after the end of HCV treatment). D) Improvement of skin lesions after one week of a higher dose of prednisone and intravenous antibiotic. 
$<1.25)$. The HCV Viral load was of 6.91 log and serum cryoglobulin was positive, without previous clinical manifestations.

He started the all oral HCV treatment with sofosbuvir 400mg / day + simeprevir 150mg /day + ribavirin $1 \mathrm{~g} /$ day $(14 \mathrm{mg} / \mathrm{kg})$, planned for twelve weeks. At the sixth week of treatment, the hemoglobin level was $9.5 \mathrm{mg} / \mathrm{dL}$ and ribavirin dose was reduced to $500 \mathrm{mg}$ per day $(7 \mathrm{mg} / \mathrm{kg})$. At the $10 \mathrm{th}$ week of treatment, he complained of pruritus in palms, feet soles, bending regions and abdomen, accompanied by scaly lesions in the abdomen and upper limbs. He denied fever, respiratory symptoms, or other complaints. On physical examination, erythematous, pruritic, scaly and flaky lesions on hands, feet and abdomen could be noted (Figures 1A and 1B). A topical corticosteroid and an oral antihistaminic were prescribed, with partial improvement.

One week after the end of treatment, he had diffuse erythroderma, a progression of lesions, blistering in upper and lower limbs, especially in the hands and feet with peeling areas, break blisters, skin fissures with bleeding and signs of secondary infection (Figure 1C).

We started outpatient treatment with oral prednisone $40 \mathrm{mg}$ daily and cephalexin (a first generation cephalosporin) $2 \mathrm{~g}$ daily. However, the skin lesions worsened, and the patient was referred to the hospital. There were no mucosal injuries, fever, eosinophilia or lymphadenopathy. Hepatic and renal functions were not compromised. He received treatment with intravenous amoxicillin-clavulanate and oral prednisone $60 \mathrm{mg}$ daily $(0.8 \mathrm{mg} / \mathrm{kg})$ because of suspected pharmacodermia with infection of skin lesions.

A skin biopsy performed on the left arm injury showed squamous-crust dermatitis, subcorneal spongiform pustule, psoriasiform epidermal hyperplasia and moderate superficial mixed inflammatory infiltrate composed of mononuclear lymphocytes and eosinophils (Figure 2). These findings were compatible with pharmacodermia. There was a progressive improvement of the skin lesions after one week of the intravenous antibiotic therapy and the higher dose of oral prednisone (Figure 1D). The patient was discharged and prednisone was tapered to $10 \mathrm{mg}$ per week until withdrawal.

When actively asked, the patient informed a previous history of pharmacodermia attributed to topiramate one year ago, that was responsive to its suspension combine with oral prednisone $60 \mathrm{mg}$ daily. The HCV RNA was undetectable at the 4th and 12 th week after treatment, setting up a sustained virological response.

\section{DISCUSSION}

We reported a case of a skin adverse event (AE) during the interferon-free treatment of HCV with sofosbuvir, simeprevir and ribavirin. Adverse events, especially skin related ones, were commonly seen with interferon and the first wave protease inhibitors telaprevir and boceprevir. Real life cohort studies reported an overall severe adverse event rate of $12 \%$, and skin manifestations could be found in up to $57 \%$ of patients treated with this interferon-based regimen?.

Some differential diagnosis should be considered

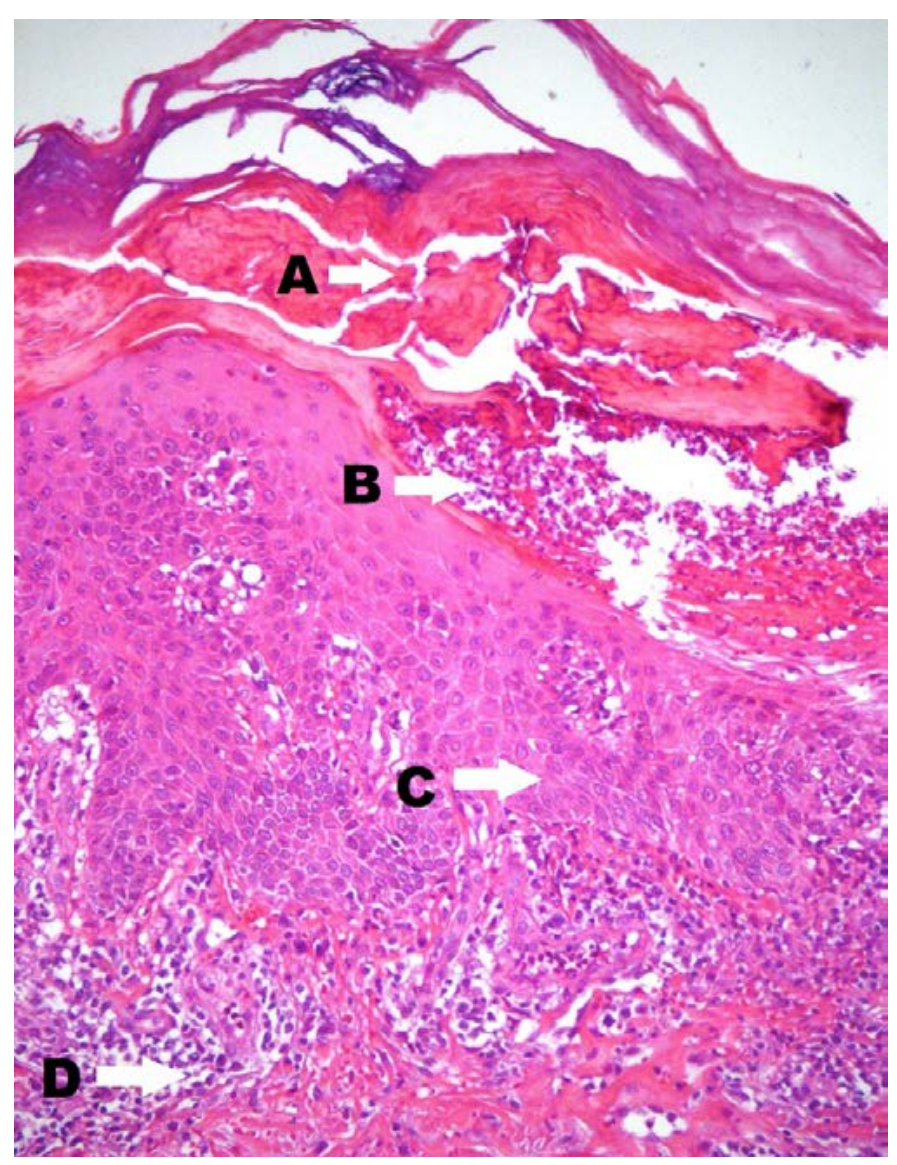

FIGURE 2. Skin biopsy showing squamous-crust dermatitis (arrow A), subcorneal spongiform pustule (arrow B), psoriasiform epidermal hyperplasia (arrow $C$ ) and moderate superficial mixed inflammatory infiltrate (arrow D) composed by mononuclear lymphocytes and eosinophils (H\&E, 125x). These findings suggest pharmacodermia. 
when an HCV patient has cutaneous manifestations, such as cryoglobulinemia, porphyria cutanea tarda, lichen planus, psoriasis, urticaria, erythema multiforme and other types of vasculitis. During antiviral treatment, the possibility of adverse reaction should always be considered, and if there is any doubt, skin biopsy must be performed ${ }^{8}$.

A meta-analysis with 4,187 patients treated with pegylated interferon plus ribavirin and one more DAA (telaprevir, boceprevir, simeprevir or sofosbuvir) showed an incidence of skin AE of 44.5\%, 25.4\%, $23.1 \%$ and $20.5 \%$, respectively ${ }^{3}$. New DAAs without interferon are well tolerated and have fewer side effects. Occasionally, it is difficult to assign a symptom to a drug or another. Some adverse effects were related with to sofosbuvir, such as fatigue, headache and renal impairment. With daclatasvir, the most frequent side effects are fatigue, headache and nausea. Simeprevir can lead to skin reactions, photosensitivity and indirect hyperbilirrubinaemia'. When ribavirin is associated with these drugs, anemia may be more frequent, as well as skin lesions. Drug interactions are frequent and must be evaluated before prescribing these treatments ${ }^{2}$.

In an American real life study with 836 HCV genotype 1 patients treated with sofosbuvir combined with simeprevir, with or without ribavirin, anemia occurred in $29.6 \%$, and fatigue in $26.5 \%$, both more common in the ribavirin group. Serious adverse events occurred in 5.3\%, more frequent in cirrhotic patients, which were almost $60 \%$ of the study population. No serious skin adverse events were identified. Discontinuation of treatment occurred in $3 \%^{10}$. In a Mexican real life study with 81 patients treated with DAAs, 35.8\% experienced AEs, mainly anemia, asthenia, and headache. There was no treatment discontinuation due to AEs ${ }^{11}$.

Simpson et al. ${ }^{12}$ reported two cases of photo-distributed lichenoid eruption attributed to sofosbuvir and simeprevir use (two and four weeks after treatment initiation). One of the patients had a history of vitiligo and allergy to ampicillin and seafood, and none of them had ribavirin on their HCV treatment schedule. Eyre et al. ${ }^{13}$ recently also reported a photo-induced skin lesion at the second week of sofosbuvir plus simeprevir treatment in an HCV transplanted patient. She received topical steroids with improvement in the following 14 days and resolution of skin lesions after HCV treatment completion. Wang et al. ${ }^{14}$ showed a case of erythema multiforme drug eruption induced by sofosbuvir and daclatasvir in an HCV patient with psoriasis vulgaris and previous history of sulfamethoxazole-trimethoprim allergy. These few case reports highlight skin lesions secondary to DAAs, mainly to sun-exposed areas, and in patients with a history of drug allergy or skin disease prior to HCV therapy initiation.

The management of skin reactions encompasses oral antihistamines and topical corticosteroids. Limited sun exposure, skin hydration and sunscreen use are also important measures. There is usually no need to stop treatment, except in the case of severe adverse reactions, when hospital admission and systemic corticosteroids may be necessary $^{3}$. The risk of anaphylaxis should be previously evaluated, but there is no objective evidence of benefit for prophylactic corticosteroids ${ }^{15}$.

Some therapeutic measures have been adopted in different groups of patients with pharmacodermia unrelated to HCV treatment, but we do not know whether these measures can be extrapolated to HCV patients with skin AE due to DAAs. It has been reported that in patients with hand-foot syndrome caused by docetaxel for breast cancer, the use of topical vitamin $E$ was effective, and perhaps the use of oral vitamin $E$ could be promising ${ }^{16,17}$. There are reports of pyridoxine replacement in preventing skin reactions caused by chemotherapy, but a recent meta-analysis concluded that its use is not effective ${ }^{18}$. Instead, celecoxib was effective in preventing moderate to severe skin reactions $^{18}$. In patients with hepatocellular carcinoma treated with sorafenib, vitamin $\mathrm{E}$ was able to improve skin lesions without reducing chemotherapy dose ${ }^{19}$.

There are no reports of adopting these strategies to prevent skin reactions due to DAAs for HCV treatment. The best approach is not yet known. Physicians should conduct detailed research on the previous history of allergies to choose a safe treatment against HCV.

\section{CONCLUSION}

Interferon-free therapies significantly improved HCV management in the recent years. They are usually safe, but can on rare occasions lead to serious adverse reactions, such as skin lesions. Patients receiving ribavirin combinations and those who had a history of pharmacodermia or skin disease may be more susceptible. There is no consensus on how to prevent skin reactions in these patients. 


\section{RESUMO}

INTRODUÇÃo: Antivirais de ação direta são as novas drogas utilizadas no tratamento da hepatite C crônica. São geralmente seguros, com boa tolerância, mas eventualmente podem causar efeitos adversos graves, e não há consenso sobre como tratá-los ou preveni-los. Descrevemos um caso de síndrome mão-pé secundária à terapia livre de interferon para hepatite C crônica. Materiais e métodos: Relatamos o caso de um paciente de 49 anos com cirrose hepática compensada secundária à hepatite C crônica, genótipo 1, virgem de tratamento, que iniciou terapia com sofosbuvir, simeprevir e ribavirina por 12 semanas. Resultados: Na sexta semana de tratamento, apresentou anemia, sendo necessária redução de dose da ribavirina. Na 20 semana, apresentou lesões eritematosas e descamativas, com prurido em mãos e pés, que teve resposta parcial ao uso de anti-histamínico oral e corticoide tópico. Não foi necessário descontinuar os antivirais, mas na primeira semana após o término do tratamento, houve piora das lesões, com sinais de infecção secundária, sendo necessárias hospitalização e terapia com antibiótico e corticoide oral, com melhora progressiva. Biópsias das lesões foram compatíveis com farmacodermia. O paciente teve resposta virológica sustentada, apesar dos efeitos adversos. Tinha história de farmacodermia há um ano, atribuída ao uso de topiramato, responsiva a corticoterapia oral. Conclusão: Os tratamentos livres de interferon raramente causam eventos adversos graves, como lesões cutâneas. Pacientes em uso de ribavirina e com história de farmacodermia ou doença cutânea prévia podem ser mais susceptíveis. Não existe consenso sobre como prevenir reações cutâneas nesses pacientes.

PALAVRAS-CHAVE: Hepatite C. Antivirais. Efeitos colaterais e reações adversas relacionados a medicamentos. Síndrome mão-pé.

\section{REFERENCES}

1. Lavanchy D. Evolving epidemiology of hepatitis C virus. Clin Microbiol Infect. 2011;17(2):107-15.

2. European Association for the Study of the Liver. EASL recommendations on treatment of hepatitis C 2016. J Hepatol 2017;66(1):153-94.

3. Patel $P$, Malik K, Krishnamurthy $K$. Cutaneous adverse events in chronic hepatitis $C$ patients treated with new direct-acting antivirals: a systematic review and meta-analysis. J Cutan Med Surg. 2016;20(1):58-66.

4. AASLD/IDSA HCV Guidance Panel. Hepatitis C guidance: AASLD-IDSA recommendations for testing, managing, and treating adults infected with hepatitis C virus. Hepatology. 2015;62(3):932-54.

5. Brasil. Ministério da Saúde. Secretaria de Vigilância em Saúde. Departamento de DST, Aids e Hepatites Virais. Protocolo clínico e diretrizes terapêuticas para hepatite $C$ e coinfecções. Brasília: Ministério da Saúde; 2015. 88p.

6. Banerjee D, Reddy KR. Review article: safety and tolerability of direct-acting anti-viral agents in the new era of hepatitis $C$ therapy. Aliment Pharmacol Ther. 2016;43(6):674-96.

7. Gordon SC, Muir AJ, Lim JK, Pearlman B, Argo CK, Ramani A, et al; HCV-TARGET study group. Safety profile of boceprevir and telaprevir in chronic hepatitis C: real world experience from HCV-TARGET. J Hepatol. 2015;62(2):286-93.

8. Cacoub P, Bourlière M, Lübbe J, Dupin N, Buggisch P, Dusheiko G, et al. Dermatological side effects of hepatitis $C$ and its treatment: patient management in the era of direct-acting antivirals. J Hepatol. 2012;56(2):455-63.

9. Lawitz E, Sulkowski MS, Ghalib R, Rodriguez-Torres M, Younossi ZM, Corregidor A, et al. Simeprevir plus sofosbuvir, with or without ribavirin, to treat chronic infection with hepatitis $C$ virus genotype 1 in non-responders to pegylated interferon and ribavirin and treatment-naive patients: the COSMOS randomised study. Lancet. 2014;384(9956):1756-65.

10. Sulkowski MS, Vargas HE, Di Bisceglie AM, Kuo A, Reddy KR, Lim JK, et al. Effectiveness of simeprevir plus sofosbuvir, with or without ribavirin, in real-world patients with HCV genotype 1 infection. Gastroenterology. 2016;150(2):419-29.

11. Chirino-Sprung RA, Dehesa M, Wolpert E, Corona-Lau C, García-Juarez I, Sánchez-Avila JF, et al. Chronic hepatitis C treatment with direct-acting antiviral agents in a real-life setting. Rev Inves Clin. 2016;68(4):203-12.

12. Simpson CL, McCausland D, Chu EY. Photo-distributed lichenoid eruption secondary to direct anti-viral therapy for hepatitis C. J Cutan Pathol. 2015;42(10):769-73.

13. Eyre ZW, Secrest AM, Woodcock JL. Photo-induced drug eruption in a patient on combination simeprevir/sofosbuvir for hepatitis C. JAAD Case Rep. 2016;2(3):224-6.

14. Wang Y, Liu P. A case of erythema multiforme drug eruption associated with erythrodermic psoriasis induced by sofosbuvir and daclatasvir. J Clin Pharm Ther. 2017;42(1):108-10.

15. Worth A, Sheikh A. Prevention of anaphylaxis in healthcare settings. Expert Rev Clin Immunol. 2013;9(9):855-69.

16. Chew $L$, Chuen VS. Cutaneous reaction associated with weekly docetaxel administration. J Oncol Pharm Pract. 2009;15(1):29-34.

17. Kara IO, Sahin B, Erkisi M. Palmar-plantar erythrodysesthesia due to docetaxel-capecitabine therapy is treated with vitamin $E$ without dose reduction. Breast. 2006;15(3):414-24.

18. Macedo LT, Lima JP, Santos LV, Sasse AD. Prevention strategies for chemotherapy-induced hand-foot syndrome: a systematic review and meta-analysis of prospective randomised trials. Support Care Cancer. 2014;22(6):1585-93

19. Bozkurt Duman B, Kara B, Oguz Kara I, Demiryurek H, Aksungur E. Hand-foot syndrome due to sorafenib in hepatocelular carcinoma treated with vitamin $\mathrm{E}$ without dose modification; a preliminary clinical study. J BUON. 2011;16(4):759-64. 